Commentationes and of the Acta, the Academy has instituted an inquiry among its members to determine what shall be its most useful function. The president emphasized that the Papal Academy differs from other national bodies of a similar nature in being truly international, since it contains members of many nationalities all of whom have equal rights and privileges. From the large number of replies to the president's inquiry, which are reproduced in the Acta, it would appear that there is a general desire that the Academy should not restrict its activities to the publication of individual scientific communications, but should take advantage of the freedom of action guaranteed by its scientific independence of race or creed to strengthen the bonds between the various sciences. The rules of the Academy have been the subject of further discussion by its council and members, and steps have been taken to ensure that in the election to vacancies in the membership the intermational character and the representation of the different sciences shall be maintained.

An annual prize, of the value of 25,000 lire, to be known as the Pius XI Prize, has been instituted. It may be awarded for any distinguished contribution to the progress of science made in the preceding ten years, either by a single important discovery or as a result of a series of systematic researches, or by a publication of great scientific interest. The president announced that the members of the Academy would shortly be called on to propose names for the 1938 award, which will be made for a distinguished contribution to the progress of biological science.

During the first year of its existence, the new Papal Academy has suffered the loss by death of three of its members, namely, Lord Rutherford, Paolo Luigioni, and the Marchese Marconi, and the main purpose of the inaugural meeting was to honour the memory of the last-named of these distinguished men of science. The Marchesa Marconi was present as an honoured guest at the ceremony. Guglielmo Marconi's immense contributions to physical science and to the development of wireless communication through space formed the subject of addresses by Prof. G. C. Vallauri of Turin, and Prof W. F. Bjerknes of Oslo, both members of the Papal Academy. The latter, who is probably the sole surviving personal pupil of Heinrich Hertz, exhibited during his discourse the original 19-page manuscript entitled "Über elektrodynamische Wellen im Luftraume und deren Reflexion" in which Hertz described the first results of his experiments on electric waves. At the close of Prof. Bjerknes' address, Hertz's manuscript was examined by His Holiness with considerable interest. As was reported in The Times of March 26, 1938, the Pope's interest in this document (which was not, as reported there, pre. sented by Prof. Bjerknes to the Papal Academy) found a practical expression in the personal gift of a sum of $£ 250$ to Hertz's widow, Mrs. Elizabeth Hertz, who is living in exile at Cambridge with her two daughters. The presentation of the gift was entrusted to Canon Marshall, of Cambridge, by Cardinal Hinsley, Archbishop of Westminster.

Pius XI, in his own address to the Academy, paid a personal tribute to the benefits conferred on mankind by the labours of Hertz and of Marconi, whose work, undoubtedly accompanied by Divine blessing, recalled the words of Schiller : "Soll das Werk den Meister loben, doch der Segen kommt von oben". The Pope also referred to his own deep-rooted interest in science and the search after truth-an interest which had in his own private life found an outlet in the love of Nature and a passion for the reading of books.

\title{
Oil from Coal
}

\begin{abstract}
IN the December 1937 issue of the New Zealand Journal of Science and Technology (19, No. 7), there is an interesting article, initialed "W. G. H.," on the production of oil from coal as seen from an Australian point of view.

The process of low-temperature carbonization is dependent for commercial success largely upon the acquisition of a market for the semi-coke produced. Such a market is readily found in Great Britain, where the smoke nuisance from raw coal burned in the domestic grate is acute. In Australia, how. ever, very little raw coal is burned in the cities and there is consequently no market for semi-coke in this direction. Low-temperature carbonization might be considered as a subsidiary method of providing coke for the Fischer Tropsch process of synthesis of hydrocarbons or to provide coke for hydrogenation.

Economically, hydrogenation is unsound from the Australian point of view. The estimated cost of a plant capable of producing 45,000,000 gallons of petrol per annum from bituminous coal is approximately $£ 11,000,000$ (Australian currency) and for one working on lignite it is nearly $£ 12,000,000$. Allowing for a return on capital of 6 per cent and for amortization in ten years, the cost would be $17 s$. $3 d$. per
\end{abstract}

gallon from bituminous coal and 18s. 2d. per gallon from lignite. The Fischer Tropsch process is no more attractive economically than hydrogenation in Australia. It has been estimated that to produce petrol at $8 d$. per gallon from a plant with an output of 9,000,000 gallons per annum, a subsidy of $£ 300,000$ or $£ 1,000$ per man per annum would be required.

The above facts admittedly do not commend any of these processes in Australia, but there are other important factors which would have to be carefully considered before deciding whether or not to erect a coal conversion plant in the Commonwealth. The chief of these are future supplies and cost of flow oil ; payment in Australian goods for foreign supplies; possible interruption of supplies in the event of war; storage problems; the likelihood of finding flow oil in the Commonwealth; and the value of a new industry as an employer of both direct and indirect labour.

All these contingencies must be assessed before any decision is taken to erect a plant which at best can only produce a local product to compete with an imported article at one third to one quarter of the cost. 